\title{
The importance of pathogen-free grapevine propagation material in regards to clonal selection and rootstock breeding in Germany
}

\author{
Rühl, Ernst H., Manty, F., Konrad, H. \& Bleser, E. \\ Forschungsanstalt Geisenheim, Fachgebiet Rebenzüchtung \& Rebenveredlung, \\ von Lade Str. 1, 65366 Geisenheim - Germany,email:e.ruehl@fa-gm.de
}

\begin{abstract}
Summary: High performing propagation material is essential for a reliable and economical production of quality grapes. Apart from genetic aspects pathogen-freedom is of prime importance in propagation material. In particular virus diseases cause major yield and quality losses and reduced longevity. This is also reflected in the current EU legislation, which focuses on the most common and dangerous viruses: GFLV, ArMV, GLRaV-I and GLRaV-III. Apart from these, locally occurring pathogens, e.g. phytoplasms or agrobacterium, are important as well and should not be present in propagation material. There are several ways to develop pathogen-free clones. Starting with already pathogen-free material is certainly the easiest case, but might not be feasible in local varieties with small acreages and limited vine numbers. In these cases the elimination of pathogens is required, either by heat therapy, tissue culture or somatic embryo genesis.
\end{abstract}

Keywords: virus, GFLV, ArMV, GLRaV-1, GLRaV-3, clonal variation vorschlagen

\section{Introduction}

The importance of healthy grapevine propagation material is known at least since Roman times (Schöffling \& Stellmach, 1993). The cause of degeneration was not known, but its effect on vine performance. Consequently, health state of plants was determined by their performance. Despite the fact that no written records exist, some kind of selection was certainly going on over centuries. Modern clonal selection commenced with Gustav Fröhlich in 1876 (Fröhlich, 1900). He assessed the performance of Silvaner vines over several years and only propagated the vine with the highest yield. Over the following years his idea of using yield as the major parameter for vine performance and health status was complemented by other German researchers resulting in a distinct clone assessment system implementing three successive steps. This system proved to be such effective that since the mid-1950s virtually only clonal material is used in Germany.

This may appear surprising as the role of virus infection in plants was only established when Stanley detected tobacco mosaic virus (Stanley, 1935). Over the next decades a number of viruses were identified as the cause of degeneration in grapevines (Table 1). With the development of ELISA and more recently PCR assays for their identification, the production of virus-tested propagation material is no longer guess-work and requires years of visual evaluation, indexing and performance trials in the field.

Virus infection can reduce both yield and vine quality significantly (Walter \& Martelli, 1996; Walter \& Martelli, 1997) (Ipachn 2004). Consequently virus-free propagation material is a key to productive vineyards and a competitive wine industry.

The aim of this paper is to summarize research in the development of pathogen-free grapevine clonal material and to present the Geisenheim approach as an example for a clonal selection program.

\section{Origin of clonal variation}

It is rather obvious that only virus-free vines show high performance, which was proved in numerous studies (Walter \& Martelli, 1996; Walter \& Martelli, 1997) (Ipach 2004). The question arises if vine health status is the major or even the only reason for clonal variances. In most cases statements on poor performance of virus infected vines are based on field observations comparing infected and non-infected vines in the same or neighbouring vineyards. Accordingly the performance divergence might not only be triggered by virus infection, but also by genetic diversities between plants, age and/or management differences.

In an attempt to assess only the virus effect, Credi and Babini (Credi \& Babini, 1997) studied solely this effect by transmitting viruses via chip budding to completely healthy clones of Albana and Trebbiano Romagnola. The results showed a significant reduction of yield and mostly also berry sugar level, if major viruses had been transmitted. Minor viruses, e.g. Fleck had no negative effect. This clearly shows that major viruses cause a strong reduction of yield and usually also berry sugar levels and should therefore not be present in propagation material. 


\section{Pathogens in Grapevines}

A large number of pathogens have been detected in grapevines so far (Table 1). The most common and damaging ones are GFLV, ArMV, GLRaV-I and GLRaV-III. This is also the reason why these four viruses are in focus of the EU COUNCIL DIRECTIVE 2002/11/EC of 14 February 2002 and its amendments. This is certainly a good compromise between a technically possible and a reasonable, affordable approach respectively. There are more virus diseases which in some European regions might be even more important than the four virus diseases mentioned by the EU legislation. In other areas Agrobacterium or phytoplasms may be of particular importance and worth eliminating. If customers have special demands in regards to pathogen tests, they can still ask their supplier for further test certificates.

A breeder is certainly well advised not to restrict himself to the four virus tests demanded by law, but he should test his original clonal mother vine for as many pathogens as possible to ensure a high sanitary status of his clones.

Table 1: Commonly detected pathogens in grapevines

\begin{tabular}{|l|l|}
\hline \multicolumn{1}{|c|}{ Nepo-Viruses } & \multicolumn{1}{c|}{ Chlostero-Viruses } \\
\hline Grapevine fanleaf virus - GFLV & $\begin{array}{l}\text { Grapevine leafroll virus - GLRaV } \\
\text { Typ-I, II, III }\end{array}$ \\
\cline { 1 - 2 } Arabis mosaic virus - ArMV & Others diseases and pathogens \\
\cline { 1 - 2 } Raspberry ringspot virus - RRV & $\begin{array}{l}\text { Corky bark, Rupestris Stem Pitting, } \\
\text { Fleck } \\
\text { Agrobacterium, Phytoplasm, } \\
\text { Viroids }\end{array}$ \\
\cline { 1 - 2 } Tomato black ring virus - TBRV \\
\cline { 1 - 2 } Strawberry latent ringspot virus -
\end{tabular}

\section{Ways to get pathogen free propagation material}

There are several ways to achieve pathogen free propagation material. The easiest and usually most economic way is to have it already present or to find it without difficulty in a vineyard. This may sound easy, but in case of highly infected varieties, it may involve an intense search for it. In case of rare varieties there might be no pathogen free material available at all. In situations like that, eliminating the virus in infected vines might be the only way possible.

The idea of all approaches is to propagate plant tissue that is most likely free of virus. There are two principle ways: heat therapy and tissue culture. In the first method vines are grown over several weeks in a glasshouse or growth chamber at about $38^{\circ} \mathrm{C}\left(100^{\circ} \mathrm{F}\right)$. Viruses can not multiply under these conditions and the new growth should thus be free from virus particles (Nyland \& Goheen, 1969; Goheen, 1972; Goheen \& Luhn, 1973).

The second approach is based on tissue culture. Meristematic tissue should be free of viruses. In a method called 'fragmented shoot apex culture', shoot tips are removed from the apex, their surface sterilized, cut to many even smaller pieces and then cultured in a sterile environment (Barlass \& Skene, 1977; Barlass \& Skene, 1978; Barlass \& Skene, 1980; Barlass \& Skene, 1980).

Both approaches may be combined. First the vines are undergoing thermotherapy, then the shoot tip will be removed, its surface sterilized and transferred into tissue culture. Another approach is to grow vines in vitro at a higher temperature.

Instead of growing shoot tips, embryogenic tissue e.g. from another culture could also be used to grow somatic embryos (Morgana et al., 2004), (Gambino, Bondaz et al., 2006; Gambino, Di Matteo et al., 2009), (BorrotoFernandez, Sommerbauer et al., 2009).

\section{Possible problems}

Regardless of what kind of approach is used, the cleaned up propagation material has to be tested again, both for the pathogens to be removed and for their performance as well.

Permanent changes in performance of the material after virus removal are possible and have been reported. They could be caused by the absence of virus itself and the better growth of the plant, or they might be induced by tissue culture and/or by plant hormones in the culture media, possibly triggering juvenility, mutation or chimeras. While it takes only three generations to go from wooden pre-base material on a breeder site to certified material for the grower, material in tissue culture might pass through 10 generations a year, thus increasing the chance of mutated or chimeric strains within a clone, as well as tightening the risk of a test tube mixup.

(Mannini, 1995) studies the clonal variation with Nebbiolo clones detecting different leaf shape and size. The 'Miquet' type showed particularly small leaves together with low yields. Both disappeared when the plant underwent thermotherapy. The Miquet type consequently was the result of a virus infection. There are numerous observations on clonal variation caused by pathogens. In Germany growers often reported Yellow Silvaner as a type within Green Silvaner or Yellow Riesling within the common White Riesling. Plants often show a slightly stunted growth, leaves curling downward at their edges and getting yellow much earlier. So far in Riesling plants of this type leafroll could be detected and, despite the yellow leaves and a riper appearance of the yellow fruit, sugar levels are lower and acidity is higher accompanied by lesser fruitiness.

\section{Geisenheim approach as an example}

There are certainly different ways to develop propagation material with a high level of pathogen-freedom. The breeder's situation and the varieties he focuses on will have an immediate influence on his strategy and there is certainly not only one way to do it. As an example the strategy at Geisenheim is outlined.

The German situation is not typical for most European regions due to an early conversion to clones. Most of the 
plantings established after 1960 had been carried out using mainly clonal material, leading to a today's acreage of nonclonal plantings of less than 500 ha, which is less than $0.5 \%$ of Germany's total acreage. These mostly old vineyards are to be found primarily on steep slopes in the Mosel region. These old plantings represent a potential source of new clones with different characters. Due to the small number of old plantings remaining, there is the need to preserve this unique genetic material.

Material in these old vineyards is identified via visual assessment, aiming for plants with a somewhat different appearance. Interesting looking plants are marked with tags and their position recorded. During winter their bud-wood is collected, tagged and brought to Geisenheim for virus testing (GFLV, ArMV, GLRaV-1, GLRaV-3). If no virus is detected, the scions are grafted to virus-tested pre-base rootstocks. Three vines are planted in the department's germplasm collection and also in a further germplasm collection in the material's original region for preservation and evaluation studies.

The material is visually assessed, yield and grape composition registered. If a clone appears to show interesting features, one of the original three vines is propagated with 12 to 24 vines for further evaluation. While the evaluation is on its way, the previously selected mother vines in the germplasm collection will undergo further virus tests. Over recent years this material was tested by PCR technique at Waite Diagnostics at the University of Adelaide, School of Agriculture \& Wine, Glen Osmond SA 5064, Australia for Grapevine leafroll associated viruses (GLRaV1, GLRaV2, GLRaV3, GLRaV4, GLRaV5, GLRaV9), GVA (Grapevine Vitivirus), GVB (Grapevine Vitivirus), GfkV-A (Grapevine fleck virus - variants A), GfkV-B (Grapevine fleck virus variants B), GFLV (Grapevine fanleaf virus), RG (Grapevine rootstock stem lesion associated virus - Red Globe Leafroll Virus), RRSV (Raspberry ringspot virus), Phytoplasms (e.g. grapevine yellows) and Agrobacterium vitis.

If the new clone is resulting free of any virus, its registration as a new clone will be applied for at the German Federal Variety Office.

The idea of this approach is to have not only a large number of genotypes preserved in germplasm collections, but also to have them available for grape production in the growers' vineyards. In this way genetic variability within traditional varieties, which developed over centuries, will be kept alive in viticulture itself. Additionally it is obvious that not all characteristics of clones can be assessed in field trials. Plant reaction to rare events like sporadic biotic and abiotic stress factors are difficult to measure in experiments, but may be observed on grower properties and add to our common knowledge of clonal behaviour.

\section{Conclusion}

Compared to many other management tools, the selection of the right rootstock, variety and clone has the advantage of being rather cheap. The appropriate choice of high performing and healthy plant material should be the prime focus in vineyard establishment. Pathogen-free grapevine propagation material is essential for reliable vine performance which means stable yields, as well as high grape quality and longevity. It is consequently a key factor for a sustainable and economically viable wine industry.

\section{References}

Barlass, M. \& Skene, K. G. M. (1978): "In vitro propagation of grapevine (Vitis vinifera L.) from fragmented shoot apices (m. dt. Zus.)." Vitis 17: 335-340,

Barlass, M. \& Skene, K. G. M. (1980): "Studies on the fragmented shoot apex of grapevine: 1. The regenerativecapacity of leaf primordial fragments in vitro." J. Exp. Bot. (Oxford)

Barlass, M. \& Skene, K. G. M. (1980): "Studies on the fragmented shoot apex of grapevine: 2. Factors affectinggrowth and differentation in vitro." J. Exp. Bot. (Oxford)

Borroto-Fernandez, E. \& Sommerbauer, T. et al. (2009): "Somatic embryogenesis from anthers of the autochthonous \&lt;i\&gt; Vitis vinifera\&lt;/i\&gt; cv. Domina leads to \&lt; i\&gt; Arabis mosaic virus\&lt;/i\&gt; -free plants." European Journal of Plant Pathology, 124 (1): 171-174.

Credi, R. \& Babini A. R. (1997): "Effect of virus and virus-like infections on growth, yield, and fruit quality of Albana and Trebbinao Romognolo grapevines.” Am J Enol Vitic, 48 (1): 7-12.

Fröhlich, G. A. (1900): "Zur Hybridisation der Reben und der Auswahl von Zuchtreben." Weinbau und Weinhandel, 18: 230-231.

Gambino, G. \& Bondaz, J. et al. (2006): "Detection and Elimination of Viruses in Callus, Somatic Embryos and Regenerated Plantlets of Grapevine.” European Journal of Plant Pathology, 114 (4): 397-404.

Gambino, G. \& Matteo, D. Di et al. (2009): "Elimination of Grapevine fanleaf virus from three Vitis vinifera cultivars by somatic embryogenesis.” European Journal of Plant Pathology, 123 (1): $57-60$.

Goheen, A. C. (1972): "Vine certification: A report on virus-free stock." Wines and Vines (San Francisco)

Goheen, A. C. \& Luhn, C. F. (1973): "Heat inactivation of viruses in grapevines (m. ital. Zus.).” Riv. Patol. Veg. (Pavia)

Ipach, U. (2004): "[Influence of grape viruses on yield and constituents of the vines]." Deutsches Weinbau-Jahrbuch

Mannini, F. (1995): Grapevine Clonal Selection in Piedmont (Northwest Italy): Focus on Nebbiolo and Barbera. Clonal Selection, Portland Oregon, American Society for Enology and Viticulture

Morgana, C. \& Lorenzo, R. et al. (2004): Somatic embryogenesis of Vitis vinifera L. (cv. Sugraone) from stigma and style culture. Vitis (), (2004) 43(4): 169-173.

Nyland, G. \& Goheen, A. (1969): "Heat Therapy of virus diseases of perennial plants.” Ann. Rev. Phytopathol., 7: 331-354.

Schöffling, H. \& Stellmach, G. (1993): Klon-Züchtung bei Weinreben in Deutschland, Waldkircher Verlag

Stanley, W. M. (1935): "Isolation of a cristalline protein possessing the properties of tobacco mosaic virus." Science, 81 (2113): 644-645.

Walter, B. \& Martelli, G. P. (1996): "Clonal selection of the vine: Sanitary and pomological selection. Influence of viroses and quality. Part I: Effects of viroses on the culture of the vine and its products." Bulletin de l'O.I.V., 69 (789-790): 945-971.

Walter, B. \& Martelli, G. P. (1997): "Clonal selection of the vine: Sanitary and pomological selection. Influence of viroeses and quality. Part II: Sanitary selection - Pomological selection." Bulletin de l'O.I.V., 70 (791-792): 5-23. 